\title{
Editorial
}

\section{Living Faithfully for Christ in Many Different Worlds}

\author{
Bruce Kaye
}

At its meeting in 1976 the Anglican Consultative Council proposed the formation of an Inter-Anglican Theological and Doctrinal Commission (IATDC). In due course the Commission was established and published a report, For the Sake of the Kingdom. The report was centrally concerned with the issue of the relations between the gospel and social or cultural forms. It is a very useful document full of insight about the nature of Anglican faith, insights which public participants in the current controversies in worldwide Anglicanism would do well to read and ponder. The report makes the striking point that there are two important aspects of a life of repentance. The first is to recognize 'the signs of God's kingdom which the gospel uncovers in every culture and which in their turn testify to the truth which is in Christ' and the second is to 'recognize that no human way of seeing and living is adequate to the transcendent reality of God's Kingdom'. ${ }^{1}$

It is the implications of these two aspects which are being worked out in the life of the Anglican communion at the present time, or rather it is those implications which should be holding the attention of Anglicans around the world and especially the bishops and the Lambeth Conference.

It is also these implications which this issue of JAS seeks to address as part of our preparation for the Lambeth Conference. In the previous issue we looked at some notable earlier perceptions of the gospel as revealed in some of the classic texts of the Anglican tradition. Here in this issue we look at a more contemporary slice of such perceptions. Stephen Pickard, an Associate Editor of JAS, has drawn together a number of articles on Anglican theological formation in different national contexts. As with the 'Classic Anglican Texts' series begun in the last issue of JAS so also with this series on 'National Anglican Identity', we will continue

1. Anglican Consultative Council and Inter-Anglican Theological and Doctrinal Commission, For the Sake of the Kingdom: God's Church and the New Creation (London: Church House, 1986), para. 83. 
to publish articles on an occasional basis. Stephen Pickard has provided an introduction to both the National Anglican Identity series generally and this particular group of articles which are published especially for the Lambeth Conference.

Also included in this issue are two articles which address different aspects of these themes. Daniel Pinti argues that the very style of Tyndale's translation of John's Gospel has evident theological implications with compelling resonances for contemporary Anglicanism, and Philip Sheldrake offers a view for Anglicans about the issues facing the Anglican Communion which comes from a sympathetic friend.

A proper consideration of the truth that Anglican faith calls us to live faithfully in the terms of the social and cultural context in which God has placed us will lead us not just to a life of repentance, as suggested by the first IATDC. It will also lead us to approach each other with all the marks of hope and humility that are appropriate to christian conversation. In the process of instantaneous cyber debate that is a truly demanding vocation. 